3 Davies DR, Tighe JR, Wing AJ, Jones NF. Immunoglobulin deposition in membranous glomerulonephritis: immunofluorescence and immunoelectron microscopy findings. Histopathology 1977;1:39-52.

4 Harrison DJ, Thomson D, Macdonald MK. Membranous glomerulonephritis. J Clin Pathol 1986;39:167-71.

5 Dunnill MS. Pathological basis of renal disease. 2nd ed. London: Baillière Tindall, 1984:555-6.

6 Mayers CP. Histological fixation by microwave heating. $J$ Clin Pathol 1970;23:273-5.

7 Login GR, Dvorak M. Microwave energy fixation for electron microscopy. Am J Pathol 1985;120:230-43.

8 Leong ASY, Daymon ME, Milios J. Microwave irradiation as a form of fixation for light and electron microscopy. $J$ Pathol 1985;146:313-21.

9 Hafiz S, Spencer RC, Lee M, Gooch H, Duerden B. Use of microwaves for acid and alcohol fast staining. J Clin Pathol 1985;38:1073-6.
10 Estrada JC, Brinn NT, Bossen EH. A rapid method of staining ultrathin sections for surgical pathology TEM with the use of the microwave oven. Am J Clin Pathol 1985;83:639-41.

11 Boon ME, Kok LP, Ouwerkerk-Noordam E. Microwavestimulated diffusion for fast processing of tissue: reduced dehydrating, clearing and impregnating times. Histopathology 1986;10:303-9.

12 Leong ASY, Milios J. Rapid immunoperoxidase staining of lymphocyte antigens using microwave irradiation. $J$ Pathol 1986;148:183-7.

Requests for reprints to: Dr KY Chiu, Histopathology Unit, Department of Pathology, University of Hong Kong, Queen Mary Hospital Compound, Pokfulam Road, Hong Kong.

\title{
Computer programs for accurate determination of size of DNA fragments in agarose gels
}

\begin{abstract}
JULIA LING, ${ }^{*} \quad \mathrm{~K} \quad$ L $\quad$ E LING, $\dagger$ K $\quad$ W CHAN, $\ddagger \quad G \quad$ L FRENCH* From the *Department of Microbiology, The Chinese University of Hong Kong, Prince of Wales Hospital, the †Department of Medicine, University College and Middlesex School of Medicine, The Rayne Institute, London, and the $\ddagger$ Department of Pathology, University of Hong Kong, Queen Mary Hospital, Hong Kong
\end{abstract}

The use of plasmid profiling for epidemiological studies of bacterial infections is an accurate and reliable method of typing, especially where no other typing scheme is available. ${ }^{1}$ Restriction endonuclease digestion of whole DNA has also been used in fingerprinting strains of the same bacterial species. ${ }^{2} 3$ All these studies require accurate estimation of the size of DNA fragments. Usually, molecular size of these fragments is determined by subjecting the DNA samples to electrophoresis on agarose, or polyacrylamide gels. The molecular size of DNA is inversely proportional to the distance travelled and may be calculated by comparison with the migration of known standards on the same gel. ${ }^{4}$ The logarithm of size in megadaltons is plotted against the logarithm of relative mobility for each of the standards. The size of the unknown DNA fragments, which is on the same gel as the standards, is read off from the curve of best fit. Such a standard curve is usually concave upward, and only a portion of it is roughly linear. The relative mobility of DNA fragments is calculated by

Accepted for publication 27 November 1986 following formula:

$$
\frac{10}{\mathrm{X}} \times \mathrm{Y},
$$

where $\mathrm{X}=$ distance travelled by one of the standards

$$
\begin{aligned}
& \mathrm{Y}= \text { distance travelled by the DNA fragment } \\
& \text { of which the relative mobility is to be } \\
& \text { calculated }
\end{aligned}
$$

This method is very inaccurate, however, if the curve of best fit is drawn subjectively. More accurate methods have been devised that relate migration and molecular size on the basis of standard mathematical formulae. These complex equations usually require computer analysis for their solution. ${ }^{5}$ Such programs are available in BASIC ${ }^{6}$ and FORTRAN. ${ }^{5}$

We have written two computer programs in MBASIC that will run on Apple II/II + /IIe computers, and these may be easily adapted for other microcomputers. The programs are relatively short and produce two solutions, one fitting a straight line and the second a parabola to results from a set of standards (figs 1 and 2). They are written based on the following equations:

$$
\begin{aligned}
y=m x & +c \text { where } \\
y=\text { molecular weight of DNA } & >\text { for linear } \\
x=\text { relative mobility of DNA } & >\text { relation } \\
m \text { and } c=\text { constants } & \\
y=a+b x+c x^{2} \text { where } & >\text { for } \\
y=\text { molecular weight of DNA } & >\text { parabolic } \\
x=\text { relative mobility of DNA } & >\text { relation }
\end{aligned}
$$

The migration distance of each standard from individual gels and its size are entered into the program. The migration of one standard is chosen and entered as "STANDARD MIGRATION" when prompted. The relative mobility will be calculated by the program. Once data are entered, results are produced almost instantaneously. 
Fig 1 Computer program for calculation of size of DNA using linear relation of its size and relative mobility on agarose gel.

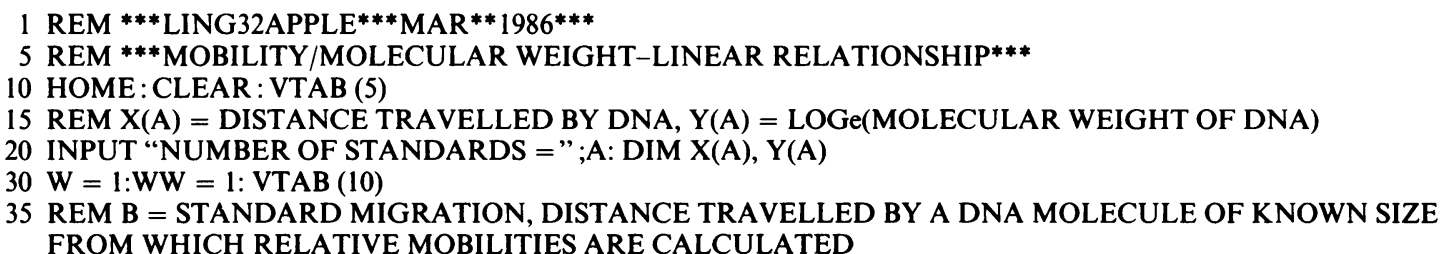


620 GET B\$: IF B $\$="$ " THEN 620

630 HOME

640 PRINT SPC( 3) "BAND DISTANCE" SPC( 4) “MW OF BAND"

650 PRINT : HLIN 0,39 AT 2

$660 \mathrm{~W}=\mathrm{W}+20$

670 RETURN

$700 \mathrm{X} \$=$ STR $\$(G)$

705 REM TO LINE UP ALL THE DECIMAL POINTS TO THE SAME POSITION ON SCREEN

710 FOR I $=1$ TO 4

720 IF MID $\$(X \$, I, 1)<>$ "." THEN IF MID\$ (X\$,I,1) < > " THEN NEXT I

730 RETURN

Fig 2 Computer program for calculation of size of DNA using parabolic relation of its size and relative mobility on agarose gel.

1 REM ${ }^{* * *}$ LING33APPLE***JUN**1986***

5 REM $^{* * *}$ MOBILITY/MOLECULAR WEIGHT-PARABOLIC RELATIONSHIP***

10 HOME : CLEAR:VTAB (5)

15 REM X(A) = DISTANCE TRAVELLED BY DNA, Y(A) = LOGe(MOLECULAR WEIGHT OF DNA)

20 INPUT "NUMBER OF STANDARDS =";A: DIM X(A), Y(A)

$30 \mathrm{~W}=1: \mathrm{WW}=1:$ VTAB $(10)$

35 REM B = STANDARD MIGRATION, DISTANCE TRAVELLED BY A DNA MOLECULE OF KNOWN SIZE FROM WHICH RELATIVE MOBILITIES ARE CALCULATED

40 INPUT "DISTANCE OF INT STD MIGRATION = "; B: HOME

50 FOR N $=1$ TO A

60 IF $N=$ W THEN GOSUB 500

65 REM C $=$ MOLECULAR WEIGHT OF DNA

70 INPUT C:Y(N) = LOG (C): VTAB $(2+\mathrm{WW}): \mathrm{WW}=\mathrm{WW}+1$

80 PRINT SPC( 5)C SPC( 15-LEN( STR \$(C)));

85 REM D = DISTANCE TRAVELLED BY DNA WITH MOLECULAR WEIGHT C

90 INPUT D:X(N) $=\mathrm{D}^{*} 10 / \mathrm{B}$

100 NEXT

200 FOR N $=1$ TO A

205 REM CALCULATE CONSTANTS AA, BB, CC FOR THE PARABOLIC EQUATION

$210 \mathrm{~S}=\mathrm{S}+\mathrm{X}(\mathrm{N}): \mathrm{S} 2=\mathrm{S} 2+\mathrm{X}(\mathrm{N}) \wedge^{\wedge} 2: \mathrm{S} 3=\mathrm{S} 3+\mathrm{X}(\mathrm{N}){ }^{\wedge} 3: \mathrm{S} 4=\mathrm{S} 4+\mathrm{X}(\mathrm{N}){ }^{\wedge} 4$

$220 \mathrm{SZ}=\mathrm{SZ}+(\mathrm{X}(\mathrm{N}) * \mathrm{Y}(\mathrm{N})): \mathrm{XY}=\mathrm{XY}+\left((\mathrm{X}(\mathrm{N}) \wedge 2)^{*} \mathrm{Y}(\mathrm{N})\right): \mathrm{SY}=\mathrm{SY}+\mathrm{Y}(\mathrm{N})$

230 NEXT

$240 \mathrm{MX}=\mathrm{S} / \mathrm{A}: \mathrm{MU}=\mathrm{S} 2 / \mathrm{A}: \mathrm{MY}=\mathrm{SY} / \mathrm{A}$

$250 \mathrm{X} 2=\mathrm{S} 2-\mathrm{A}^{*}\left(\mathrm{MX} \wedge{ }^{\wedge}\right): \mathrm{X} 3=\mathrm{S} 3-\mathrm{A}^{*} \mathrm{MX} \mathrm{X}^{*} \mathrm{MU}: \mathrm{XX}=\mathrm{S} 4-\mathrm{A}^{*}\left(\mathrm{MU}^{\wedge}\right.$ 2)

$260 \mathrm{Y} 1=\mathrm{SZ}-\mathrm{A} * \mathrm{MX} * \mathrm{MY}: \mathrm{Y} 2=\mathrm{XY}-\mathrm{A} * \mathrm{MU} * \mathrm{MY}$

$270 \mathrm{CC}=((\mathrm{X} 3 * \mathrm{Y} 1)-(\mathrm{X} 2 * \mathrm{Y} 2)) /\left(\left(\mathrm{X} 3{ }^{\wedge} 2\right)-(\mathrm{X} 2 * \mathrm{XX})\right)$

$280 \mathrm{BB}=(\mathrm{Y} 1 / \mathrm{X} 2)-(\mathrm{CC} *(\mathrm{X} 3 / \mathrm{X} 2))$

$290 \mathrm{AA}=\mathrm{MY}-\mathrm{BB} * \mathrm{MX}-\mathrm{CC}^{*} \mathrm{MU}$

300 HOME $: W=1: W W=1:$ VTAB $(10)$

310 PRINT "NUMBER OF BANDS"

315 REM E = NUMBER OF DNA BANDS FOR SIZE ESTIMATION

320 INPUT "FOR ESTIMATIONS = "; E: HOME

330 FOR $N=1$ TO E

340 IF $N=$ W THEN GOSUB 600

345 REM F1 = DISTANCE TRAVELLED BY DNA MOLECULE, $F=$ RELATIVE MOBILITY OF DNA

350 INPUT F1:F $=F 1 * 10 /$ B: $\operatorname{VTAB}(2+\mathrm{WW}): \mathrm{WW}=\mathrm{WW}+1$

355 REM G $=$ MOLECULAR WEIGHT OF DNA CALCULATED FROM AA, BB AND CC CONSTANTS

$360 \mathrm{G}=\operatorname{INT}\left(\left(\operatorname{EXP}\left(\mathrm{AA}+\mathrm{BB} * \mathrm{~F}+\mathrm{CC}^{*} \mathrm{~F}^{\wedge} 2\right)\right) * 100+.5\right) / 100$

370 GOSUB 700

380 PRINT SPC( 5)F1 SPC( 15 - LEN (STR \$ (F1))) SPC( 5 - I)G;

390 PRINT : NEXT

400 PRINT "PRESS ANY KEY"

410 GET BS: IF BS $="$ " THEN 410

420 HOME : VTAB (10)

425 REM FOR MORE CALCULATIONS USING THE SAME AA, BB AND CC CONSTANTS

430 PRINT "MORE CALCULATIONS USING"

440 INPUT "EXISTING DATAS (Y/N) ?"; AS

450 IF LEFT $(A \$, 1)=$ "Y" THEN GO TO 300 
460 HOME : END

500 IF $N=1$ THEN 530

510 PRINT "PRESS ANY KEY":WW = 1

515 REM PRINT TITLES ON SCREEN: MW OF BAND (INPUT STANDARD VALUES); BAND DISTANCE (INPUT CORRESPONDING DISTANCE TRAVELLED)

520 GET B\$: IF B\$ = " "THEN 520

530 HOME

540 PRINT SPC( 4) "MW OF BAND" SPC( 3) "BAND DISTANCE"

550 GOSUB 650

560 RETURN

600 IF N $=1$ THEN 630

610 PRINT "PRESS ANY KEY":WW = 1

615 REM PRINT TITLES ON SCREEN: BAND DISTANCE (INPUT DISTANCE TRAVELLED BY SAMPLE DNA); MW OF BAND (MOLECULAR WEIGHT OF SAMPLE DNA CALCULATED TO 2 DECIMAL POINTS)

620 GET BS: IF B $\$="$ "THEN 620

630 HOME

640 PRINT SPC( 3) "BAND DISTANCE" SPC( 4) "MW OF BAND"

650 PRINT : HLIN 0,39 AT 2

$660 \mathrm{~W}=\mathrm{W}+20$

670 RETURN

$700 \times \$=$ STR $\$(G)$

705 REM TO LINE UP ALL THE DECIMAL POINTS TO THE SAME POSITION ON SCREEN

710 FOR I $=1$ TO 4

720 IF MID $(X \$, I, 1)<>$ "." THEN IF MID\$ (X\$,I,1) < > " THEN NEXT I

730 RETURN

Both computer programs have been shown to be accurate in estimating the size of DNA fragments. Tables 1 and 2 show the actual molecular weights and the molecular weights estimated by the linear and parabolic programs of Hind III digests of phage $\lambda$, and of standard plasmids of known size, respectively.

It should be noted that for the greatest accuracy, standards of similar sizes to the unknowns should be used for both linear and parabolic programs. Where

Table 1 Estimation (standard error of mean) of sizes of Hind III fragments of phage $\lambda$

\begin{tabular}{|c|c|c|}
\hline \multirow{2}{*}{$\begin{array}{l}\text { Fragment size } \\
\text { (Mdal) }\end{array}$} & \multicolumn{2}{|c|}{$\begin{array}{l}\text { Estimated fragment size (Mdal) by } \\
\text { program }\end{array}$} \\
\hline & Linear & Parabolic \\
\hline $\begin{array}{l}6 \cdot 08 \\
4 \cdot 23 \\
2 \cdot 82 \\
1 \cdot 5 \\
1 \cdot 31\end{array}$ & $\begin{array}{l}5.76(0.22) \\
4.29(0.06) \\
3.01(0.16) \\
1.53(0.03) \\
1.26(0.02)\end{array}$ & $\begin{array}{l}6.08(0.04) \\
4.22(0.06) \\
2.82(0.05) \\
1.50(0.04) \\
1.31(0.03)\end{array}$ \\
\hline
\end{tabular}

Table 2 Estimation (standard error of mean) of sizes of standard plasmids

\begin{tabular}{|c|c|c|c|c|c|}
\hline \multirow{2}{*}{$\begin{array}{l}\text { Plasmid } \\
\text { No }\end{array}$} & \multirow{2}{*}{\multicolumn{2}{|c|}{$\begin{array}{l}\text { Plasmid } \\
\text { size } \\
\text { (Mdal) }\end{array}$}} & \multicolumn{3}{|c|}{$\begin{array}{l}\text { Estimated plasmid size (Mdal) by } \\
\text { program }\end{array}$} \\
\hline & & & Linear & & Parabolic \\
\hline $\begin{array}{l}\text { TP } 129 \\
\text { TP } 125 \\
\triangle \\
\times \\
\text { RP 1 } \\
\text { TP } 120 \\
\text { Sa } \\
\text { TP } 193\end{array}$ & $\begin{array}{l}77 \cdot 6 \\
64 \cdot 0 \\
59 \cdot 4 \\
40 \cdot 0 \\
37 \cdot 8 \\
31 \cdot 7 \\
25 \cdot 9 \\
20 \cdot 2\end{array}$ & $\cdot{ }^{\prime} \cdot 1$ & $\begin{array}{l}74.29(3.83) \\
64.73(2.10) \\
57.78(1.55) \\
42.48(1.12) \\
39: 20(1.32) \\
32.25(1.51) \\
24.56(1.20) \\
20.35(0.85)\end{array}$ & $\because$ & $\begin{array}{l}76.23(2.63) \\
65.58(2.44) \\
57.72(1.80) \\
41.45(1.23) \\
37.91(1.77) \\
31.49(0.81) \\
24.71(0.92) \\
20.96(0.58)\end{array}$ \\
\hline
\end{tabular}

high molecular weight unknowns are to be estimated, the parabolic relation seems to be more accurate. Meyers $e t a l^{4}$ showed that for high molecular weight DNA, there is a less linear relation between size and mobility. The parabolic program is also recommended for unknowns covering a wide range of sizes, especially when large sized standards are not available.

\section{References}

I Farrar WE Jr. Molecular analysis of plasmids in epidemiologic investigation. J Infect Dis 1983;148:1-6.

2 Falk ES, Bjorvatn B, Danielsson D, Kristiansen B, Melby K, Sorensen B. Restriction endonuclease fingerprinting of chromosomal DNA of Neisseria gonorrhoeae. Acta Pathol Microbiol Immunol Scand (Sect B) 1984;92:271-8.

3 Bradbury WC, Murray RGE, Mancini C, Morris VL. Bacterial chromosomal restriction endonuclease analysis of the homology of Bacteroides species. J Clin Microbiol 1985;21:24-8.

4 Meyers JA, Sanchez D, Elwell LP, Falkow S. Simple agarose gel electrophoretic method for the identification and characterization of plasmid deoxyribonucleic acid. $J$ Bacteriol 1976;127:1529-37.

5 Schaffer HE, Sederoff RR. Improved estimation of DNA fragment lengths from agarose gels. Anal Biochem 1981;115:113-22.

6 Duggleby RG, Kinns H, Rood JI. A computer program for determining the size of DNA restriction fragments. Anal Biochem 1981:110:49-55.

7 Russell GC. DNA size-a program to calculate the sizes of DNA fragments in agarose gels from the mobility of standard fragments. Binary 1984;3:31-2.

Requests for reprints to: Dr Julia Ling, Department of Microbiology, The Chinese University of Hong Kong, Prince of Wales Hospital, Shatin, New Territories, Hong Kong. 